\title{
THE ROLE OF BUSINESS EDUCATION IN THE DEVELOPMENT OF ENTREPRENEURSHIP IN THE MEMBER STATES OF THE EUROPEAN UNION
}

\author{
SŁAWOMIR KUREK, TOMASZ RACHWAt \\ Institute of Geography, Pedagogical University of Cracow \\ Podchorążych 2, 30-084 Kraków, Poland \\ e mail:sgkurek@up.krakow.pl T.Rachwal@up.krakow.pl
}

\begin{abstract}
The paper aims at analysing the role of entrepreneurship in the educational strategy of European Union as well as the position of business education in the systems of national education in selected European states in relation to the level of entrepreneurial development in these countries, measured by the indexes of the number of firms per person according to various size classes. An attempt will be made to determine to what degree the guidelines and objectives of business education in particular countries create favourable conditions for growing new firms, especially in the SME sector.
\end{abstract}

Key words: entrepreneurship, business education, educational strategy, entrepreneurial development, SMEs, European Union

\section{INTRODUCTION}

It is widely assumed that entrepreneurship is one of the basic factors of socio-economic development of spatial systems on a different scale. It is just an activity of different types of enterprises: from micro-companies among which a major part is played by one-man firms of private persons, through small and medium-sized enterprises to large national companies and international corporations, that shape the economy of local, regional and national patterns as well as the global economy. The development of entrepreneurship is considered to be an important factor of economic growth in the states with their economies under transition.

Simultaneously, contemporary tendencies for civilisation growth, involving the construction of knowledge-based economy and the development of information 
society, require constant modernisation of the didactic process at all educational levels, so as to adjust the objectives and contents of school education to the challenges posed to the preparation of the society for living in the contemporary world. It seems to be of great significance in case of Poland and other countries of Central and Eastern Europe, where the continuing processes of economic transition occurring in the view of increasing globalisation of world economy, and European integration have an impact on the necessity of an adequate preparation of young people to function in the ever more complex social and economic systems. This preparation takes place, among others, by developing entrepreneurial attitudes at all stages of human development. For this reason, the need arises to pay attention to an exceptional role of business education in the education systems of particular countries. Moreover, the role of business education is particularly exposed during present economic crisis, which first symptoms were observed at the beginning of 2008. Under conditions of production and employment limitations, which lead to increased unemployment, a man's ability to face these difficulties is of great importance. This ability results not only from individual, inborn predisposition bound by determined personality but also is an effect of developing entrepreneurial attitudes in the course of school education. Taking into account high unemployment rates and difficulties in finding a job, this kind of attitude allows for self-employment and the development of own family business.

In light of presented premises, this paper aims at analysing the role of entrepreneurship in the educational strategy of European Union as well as the position of business education in the systems of national education in selected European states in relation to the level of entrepreneurial development in these countries, measured by the indexes of the number of firms per person according to various size classes. The data for analysing SME sector and producing cartograms were taken from Eurostat database, namely Structural Business Statistics (SBS), which includes industry, construction and services (NACE Sections $\mathrm{C}$ to K). Financial services (NACE Section J) were not taken into account because of their specific nature and the limited availability of most types of standard business statistics in this area. SBS does not cover agriculture, forestry and fishing, nor public administration and (largely) non-market services such as education and health. An attempt will be made to determine to what degree the guidelines and objectives of business education in particular countries create favourable conditions for growing new firms, especially in the SME sector. In the discussion the issues of business education at tertiary level were not taken into account. Firstly, because it is a broad issue, which requires separate treatment and secondly, on account of research assumptions based on a conviction that business education should be carried out at lower levels of education within compulsory training (concerning all pupils). After all, it is difficult to assume that this kind of knowledge and skills will be acquired by only part of the pupils who are going to choose a secondary school with an economic profile or business studies, while the rest who are going to choose human subjects, will be deprived of this possibility. 


\section{ENTREPRENEURSHIP AS A KEY COMPETENCE AND ONE OF THE BASIC OBJECTIVES OF EDUCATIONAL STRATEGY OF EUROPEAN UNION}

It should be underlined that the issues of raising the level of education in entrepreneurship and preparation of the young for professional career in new economic realities, including establishing own firm, is not a subject of particular interest only in Poland or other states of Central-Eastern Europe with their economic systems under transition. According to the report on developing key competencies within compulsory education in particular educational systems in European countries (Key Competencies... 2002), faced with the following phenomena:

- EU enlargement,

- an ageing population,

- rising migration,

- increasingly complex career paths,

- consistently high levels of unemployment and the associated risk of social exclusion,

European countries, also including "old" UE-15 Member States, have started to take a closer look at those skills and key competencies likely to be needed by adults in the future. European countries are increasingly concerned to identify the knowledge, skills, competence, abilities and attitudes that will allow their citizens to play an active part in this emerging knowledge-driven society. The attempts to establish these essential attributes needed to participate effectively in political, economic, social and cultural life are being pursued both at the national or international level. A special focus of this effort is the relationship between the basic education and economy. The effectiveness of the former in preparing young people for successful economic and social integration has been increasingly questioned. (Key Competencies... 2002). As a result of a long-standing study and a long debate in a forum of various UE institutions (mainly Working Group on Basic Skills, Foreign Language Teaching and Entrepreneurship of European Commission), entrepreneurship was recognised as one of eight key competences for lifelong learning, including among others communication in the mother tongue and foreign languages, mathematical competence and basic competences in science and technology (Recommendation... 2006). This competence called "sense of initiative and entrepreneurship" was broadly defined (Recommendation... 2006, p. 8-9):

"Sense of initiative and entrepreneurship refers to an individual's ability to turn ideas into action. It includes creativity, innovation and risk-taking, as well as the ability to plan and manage projects in order to achieve objectives. This supports individuals, not only in their everyday lives at home and in society, but also in the workplace in being aware of the context of their work and being able to seize opportunities, and is a foundation for more specific skills and knowledge needed by those establishing or contributing to social or commercial activity. This should include awareness of ethical values and promote good governance. Essential knowledge, skills and attitudes related to this 
competence: Necessary knowledge includes the ability to identify available opportunities for personal, professional and/or business activities, including 'bigger picture' issues that provide the context in which people live and work, such as a broad understanding of the workings of the economy, and the opportunities and challenges facing an employer or organisation. Individuals should also be aware of the ethical position of enterprises, and how they can be a force for good, for example through fair trade or through social enterprise. Skills relate to proactive project management (involving, for example the ability to plan, organise, manage, lead and delegate, analyse, communicate, de-brief, evaluate and record), effective representation and negotiation, and the ability to work both as an individual and collaboratively in teams. The ability to judge and identify one's strengths and weaknesses, and to assess and take risks as and when warranted, is essential. An entrepreneurial attitude is characterised by initiative, pro-activity, independence and innovation in personal and social life, as much as at work. It also includes motivation and determination to meet objectives, whether personal goals, or aims held in common with others, including at work".

The development of this and other key competences was recognised as extremely important in endorsed in 2002 the Education and Training 2010 work programme, which constitutes a solid framework of European cooperation in the field of education and training, based on common objectives, and aimed at the improvement of the quality of education in UE-Member States. The Council of European Union, seeing positive effects of this programme, acknowledged that if Europe wants to become the most competitive and dynamic world knowledge-driven economy, it still presents a significant challenge and these activities should be continued in the perspective of the year 2020. In Council conclusions of 12 May 2009 meeting on a strategic framework for European cooperation in education and training, it was stressed that these activities should be oriented to four strategic objectives, of which one of them was defined as: "enhancing creativity and innovation, including entrepreneurship, at all levels of education and training" (Council conclusions... 2009, p.4). An attention to a large role of shaping entrepreneurial attitude was also paid in Communication from The Commission to The Council, The European Parliament, The European Economic and Social Committee and The Committee of The Regions "Implementing the Community Lisbon Programme: Fostering entrepreneurial mindsets through education and learning" (Communication... 2006). In this document a key role of education in entrepreneurship in the development of SME sector and the whole economy was underlined through a confirmed positive correlation between entrepreneurship and economic growth, particularly in high-income countries, although GDP growth is also influenced by many other factors. The capacity of an economy to successfully compete and grow depends on balancing the stock of enterprises through encouraging more start-ups and managing business transfer. Therefore, sustainable growth based on innovation and excellence requires an increasing number of startups, which are likely to provide more and better jobs. As a result, countries exhibiting a greater increase in entrepreneurship rates tend to show greater subsequent 
decreases in unemployment rates. On the other hand, social systems are increasingly under pressure due to the shrinking labour force and for this reason, more highgrowth and innovative SMEs are needed if Europe wants to successfully maintain its social model. Moreover, it was emphasized that entrepreneurship education develops creativity and self-confidence among young people, which is not only limited to start up a new business or create a new job but also is a key competence in social life, helping them to act in a responsible way.

As an effect, in many EU-Member States the work was undertaken on reforming the education systems in such a way that they would be in favour of developing competences related to entrepreneurship. It demands that Poland and other countries of Central and Eastern Europe be under competitive pressure, resulting from the modernisation of teaching content and education systems in other countries, which also discerned the necessity of increasing education efficiency in entrepreneurship, although very often it already represents very high level. It has an impact on the necessity of introduction of exceptionally courageous, well thought out and with the highest factual level, programme changes in business education, taking into account modern and future, projected determinants of human development. Such attempts are made in Poland which is manifested by the curriculum reform, implemented since the beginning of the current school year. However, it should be noticed at this point, that as recent studies show (Rachwał 2009), the reform has not resulted in significant increase of the role of business education in Poland, which puts our country in an unfavourable situation against other EU states.

\section{THE RANGE OF BUSINESS EDUCATION IN SELECTED EU COUNTRIES}

Business education in EU countries is carried out first of all on the secondary school level. In European documents admittedly attention is paid to the fact that in education process the foundations of shaping all key competences should be already laid in primary school. In an announcement of the Commission (Communication... 2006) it was stated that "In a number of Member States, curricula already encourage schools to guide children towards taking initiative and responsibility. However, examples of more explicit entrepreneurship education are few. In general terms, coherent initiatives or programmes led by education authorities are still rare in primary education; activities are often led by external actors, such as non-profit organisations supported by the private sector."

Some countries try to introduce teaching content related to entrepreneurship within the classes in civic education. It is very significant because the foundations of all competences leading to better management of one's own life are laid in the early years of education. Entrepreneurial attitudes are developed with the help of nurturing qualities such as creativity and a spirit of initiative. This is best done through active learning based on children's natural curiosity. In addition, learning about society should also include an understanding of the role of entrepreneurs in the com- 
munity as well as early knowledge of and contact with the world of work and business. A good example of such approach is Luxembourg, where the sixth-year (11/12 yearold pupils) French-language programme has a section devoted to starting up a business, based on the strip cartoon "Boule and Bill set up a business", and this is used in all primary schools. The cartoon is also used in the mathematics programme for introducing basic financial analysis.

In most EU-Member States these elements are introduced only at lower secondary level (in Poland called gymnasium) or in the end of basic education-depending

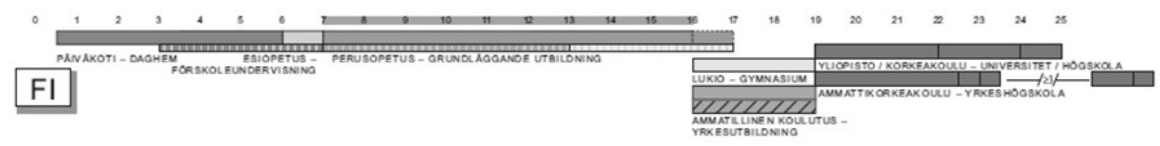

FR
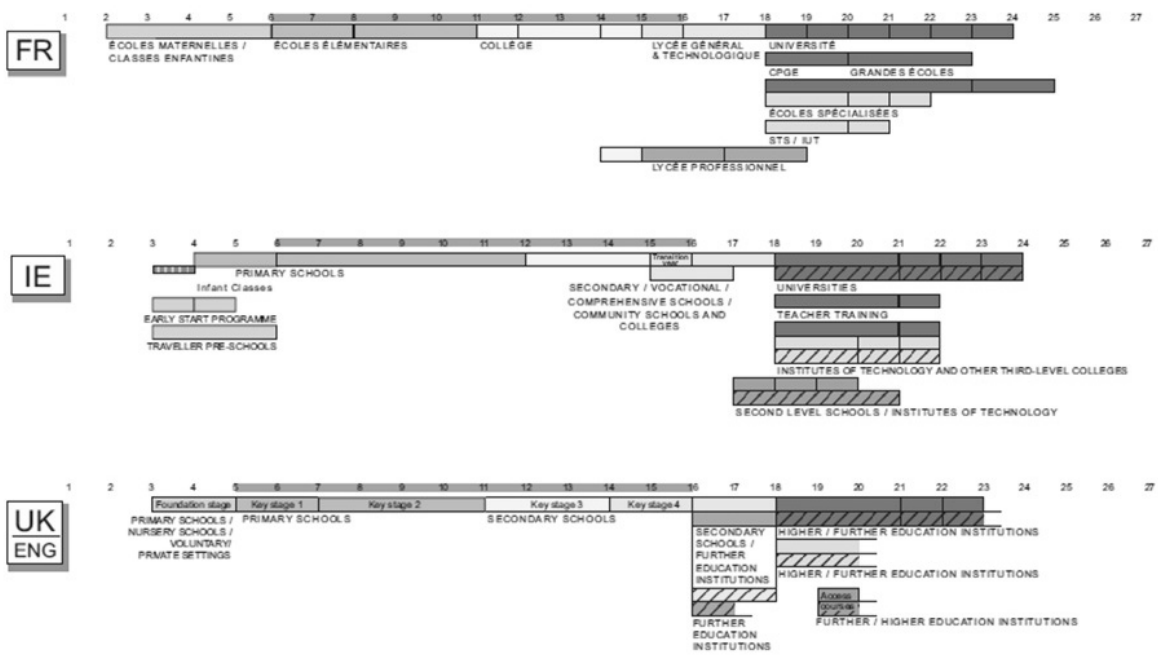

PL

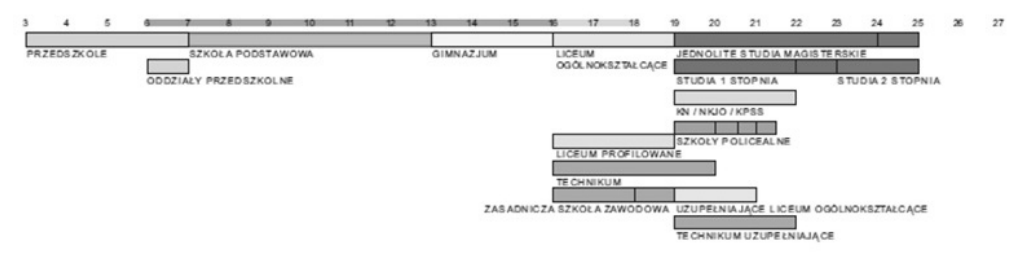

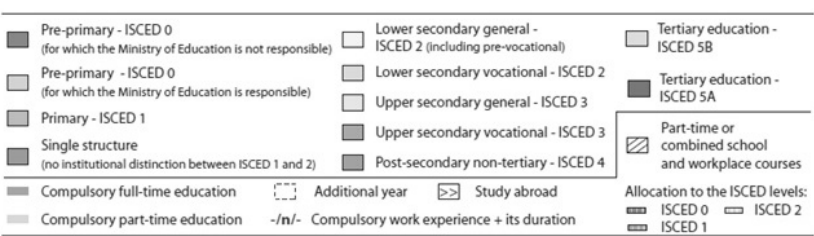

Figure 1. The structure of education systems (2009/10) in selected UE-Member States Source: Key Data on Education in Europe 2009, Erydice, Brussels. 
on the school system. The variety of education systems in particular EU-Member States (Figure 1) as well as different place of economic content in education does not allow for simple direct comparison of the place of business education in specific types of school. For example, in UK (England) some of the teaching content of the subject „citizenship” carried out within secondary education (level: Key Stage 3 and 4) concerns business education. In light of the proposition of the programme of study requirements (Citizenship... 2002) this content can be carried out in two programme units entitled "How the economy functions" and „Business and enterprise“. Moreover, in schools non-statutory classes can be carried out „Economic wellbeing and financial capability”, in which the students should understand the economic and business environment as well as the functions and uses of money.

Finland is an example of EU-Member State, which tries to implement fully the recommendation on key competences with a particular consideration of entrepreneurship. It is manifested by close cooperation between the National Board of Education and the Ministry of Trade and Industry in developing education and training for entrepreneurship, including the organisation of lectures and seminars, dissemination of ideas and examples of good practice, as well as paying attention to material on various websites. Since 2002, the National Education and Training Committee for Entrepreneurship, representing the Education and Trade and Industry ministries, SME organisations and the main social partners, has been developing and evaluating activities in this area. The main organisation objective is to demonstrate to teachers' trainers that entrepreneurship is a relevant objective at all levels of education as many do not initially consider it to be a normal feature of school students' curriculum, rather a subject for adults only. The country's new national core curriculum for basic education and upper secondary schools includes a cross-curricular participatory citizenship and entrepreneurship theme. According to it, students are taught to act with a sense of enterprise and initiative, become engaged citizens, be familiar with the operating principles of entrepreneurship and understand the significance of work and entrepreneurship to both individuals and society. (Baldaasarii and Sivala 2006).

In light of new core curriculum, business education in Finland is already carried out on the stage of basic education (compulsory school) in upper class forms within the subjects „social studies” and „home economics”. Within social studies one of the objective is as follows (National core... 2004):

"The pupils will:

- learn the fundamentals of entrepreneurship and understand its importance as a source of a society's well-being"

Core contents of this subject comprise among others (National core... 2004):

Managing one's finances

- principles of managing private finances

- work and entrepreneurship

\section{Economics}

- the individual and households as consumers and economic players 
- the importance of foreign trade and the global economy

Economics policy

- fluctuations in the economic cycle; unemployment, inflation and their impacts on households

- taxation and public finances".

Within "home economics" classes, the objectives and core contents are connected with the functioning of a household (also with good manners at home and healthy food) including planning one's household budget.

In France, however, business education at lower secondary level (college) practically does not exist (with the exception of some contents in a subject "technologie"). The foundations of the subject civic education (Éducation civique) concentrate on citizenship, not business matters. At upper secondary level (lycée), students who choose economic-social profile (Série Économique et sociale) have extended programme block called „Economics and social science”. However, in relation to other students business education was reduced to minimum. This approach is not in accordance with the recommendation of the European Commision (Communication... 2006), in which it was clearly underlined that curricula for schools at all levels should explicitly include entrepreneurship as an objective of education, accompanied by implementation guidelines.

A good example of extended business education is Ireland. In lower-secondary school (ending with Junior Certificate) classes are carried out within "Home Economics" and "Business Studies", while in upper-secondary school (ending with Leaving Certificate), beside such subjects like "Economics” and „Home Economics” a pupil has a possibility to attend the following classes: „Business”, “Agricultural Economics" and "Accounting”. The main objectives of subject „Business”, in which in to a large degree a preparation for running own business is carried out are (Business... 1996):

- to contribute to a balanced and appropriate general education, leading to the personal and social development of students through a study of business and enterprise;

- to encourage initiative and self-reliance in each student;

- to develop a clear understanding of the role of enterprise, to encourage the development of appropriate enterprise learning skills, and to generate in students a positive and ethical attitude to enterprise in personal, business and public life;

- to develop a critical understanding of the overall environment in which business functions;

- to help prepare students for participation in a changing business environment for adult and working life and also as a basis for further education;

A preliminary analysis of school curricula in selected countries leads to a statement that in countries which joined European Union later (as Ireland or Finland) business education starts earlier and is more extended than in old "core" EU states. New EU-Members try to follow this, extending their business education. In Poland, 
it is displayed, among others, in introducing in 2002 a new subject called "Basics of Entrepreneurship" to all types of upper secondary schools as well as extending the teaching content in the subject "Civic Education" by business contents within the module called "education for active participation in economic life". Unfortunately as recent study on teacher's opinion showed (Tracz and Rachwał 2007; Rachwał 2009) the consequence of the fact that this module is not a separate subject but a part of "Civic Education", this contents is marginalised by teachers. The following curriculum reform, implemented from the school year 2009/2010 has not solved the problem: business content within this subject remained but they were not even marked off as a separate module. In addition to that, the most often within the preparation for teaching civic education entrepreneurial content were not carried out to such a large extent. It remains to hope that teachers of this subject will treat the regulations of new core curriculum seriously and will raise their qualifications as their own initiatives (by taking part in different training courses and post-graduate studies) in order to carry out the teaching content professionally. Having limited number of units for the accomplishment of "Civic Education" subject as well as very extended curriculum guidelines it would be very difficult, however. Moreover, within the curriculum reform it is expected to introduce a non-compulsory subject called "Economy in Practice" since the year 2011/2012 in upper secondary schools. It is a supplementary subject, being the extension of "Basics of Entrepreneurship" subject. Students who are going to choose it, will be introduced into the realities of the functioning of economy, preparing them to enter the labour market. This subject aims to use the students' knowledge concerning economic issues into practical activities taking up within and outside school. Students can run mini-companies at school, take part in simulation business games, carry out an analysis of selected market or take up other projects of economic nature. The recommended method of work is a project as it creates favourable conditions for a comprehensive development of student's personality. According to the guidelines, the teacher should create situations in which the student independently take decisions concerning the sort and range of economic enterprises. Practical approach to economic issues enables the student to gain knowledge independently and acquire skills supporting entrepreneurial attitudes.

Unfortunately, as it was shown in a previous analysis (Rachwał 2009), the chances for selection of this subject by students, who will surely concentrate on preparation for school leaving exams in key subjects, are very small. A detailed analysis of a new core curriculum in entrepreneurship education in Poland allows for drawing a conclusion, that an established relatively low number of classes in entrepreneurial education, lack of economic content in primary school, as well as lack of possibilities of running, this subject at an extended level in secondary school and choosing it as a school leaving exam subject indicate the fact, that entrepreneurship as a key competence of European education area is not crucial from the point of view, of new programme guidelines. 


\section{EDUCATION AND THE DEVELOPMENT OF SME SECTOR}

Increasing the level of business education in Europe, as it is expected, should result in more dynamic development of enterprises, particularly from the sector of small and medium enterprises. As it was noticed in Communication from The Commission to The Council, The European Parliament, The European Economic and Social Committee and The Committee of The Regions "Implementing The Community Lisbon Programme: Modern SME Policy for Growth and Employment" (Communication... 2005), the role of this sector in economy is crucial. In this document, much attention was paid to the fact that small and medium-sized enterprises (SMEs) defined as having fewer than 250 employees, make up a large part of Europe's economy. There are some 23 million of them in the European Union, providing around 75 million jobs, contributing up to $80 \%$ of employment in some industrial sectors, such as textiles, construction or furniture as well as accounting for $99 \%$ of all enterprises. SMEs are a key part of European industry, being major source of entrepreneurial skills, innovation and contribute to economic and social cohesion.

The analysis of the percentage of SME sector in total number of enterprises (Figure 2) shows that this share is the highest in countries of Southern Europe (Spain, Portugal, Italy, Greece). The index of the number of enterprises per 100 inhabitants (defined most often as an entrepreneurship index) is also the highest in countries of Southern Europe as well as in Scandinavia, Czech Republic, Hungary and Slovenia (Figure 3). Relatively low indexes occur in the United Kingdom, Ireland, Germany, Rumunia and Bulgaria.

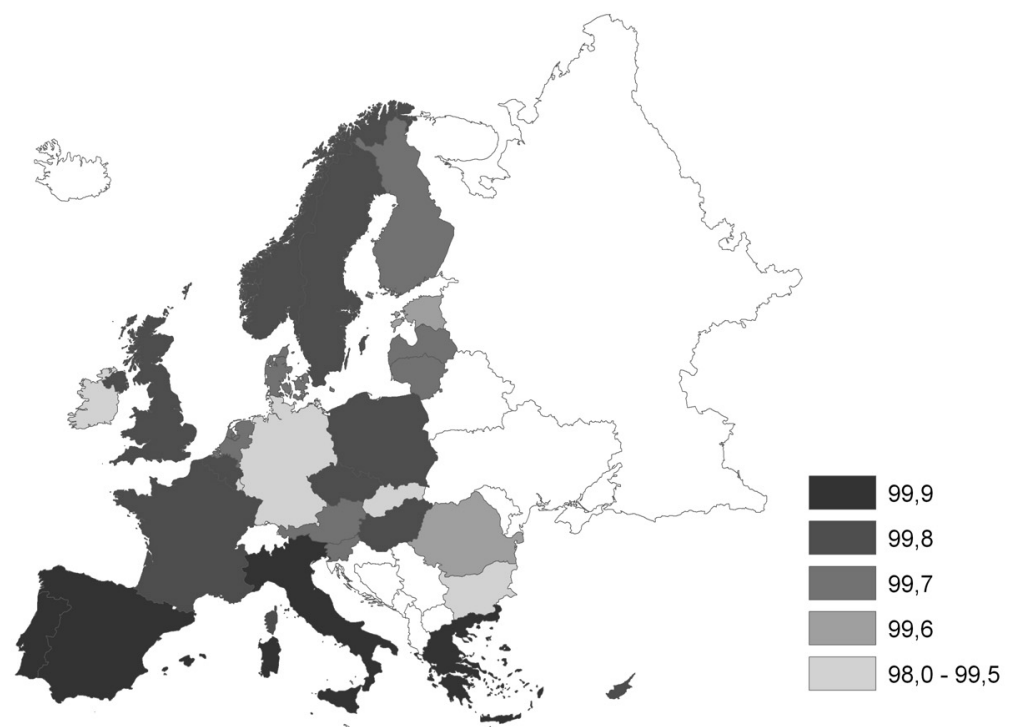

Figure 2. The percentage of SMEs in total enterprises 
High indexes of the share of SMEs in total enterprises obviously do not indicate that they play such an important role in the activation of labour force, nonetheless it should be realised that $3 / 4$ of employment in Europe is concentrated in SME sector. An analysis of an index of SMEs percentage in total employment (Figure 4) shows

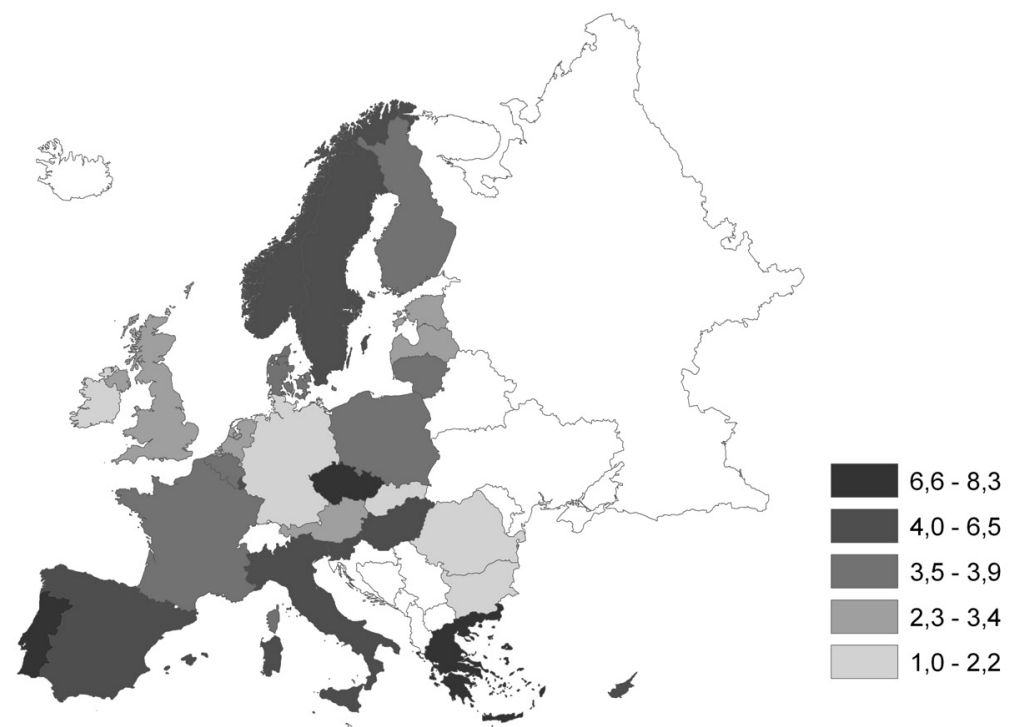

Fig. 3. The number of SMEs per 100 inhabitants

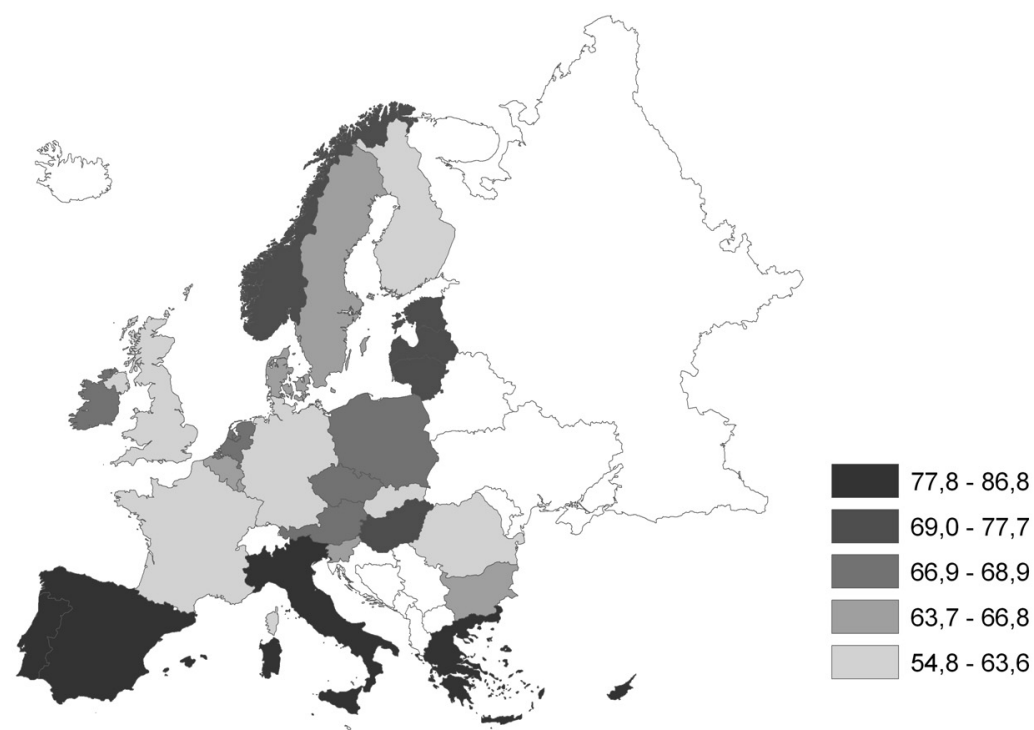

Figure 4. The percentage of SMEs in total employment 
that the highest values are represented by countries o Southern Europe (Spain, Portugal, Italy, Greece, Cyprus) as well as the Baltic states and Hungary.

An analysis of dynamics of changes in the number of enterprises in this sector indicates a dynamic growth in the numberof SMEs in recent years, in addition to which the highest values were recorded in Portugal, France, Slovakia and Lithuania (Figure 5). Only in three EU-Member States (Czech Republic, Hungary, Bulgaria) a slight downward trend was observed.

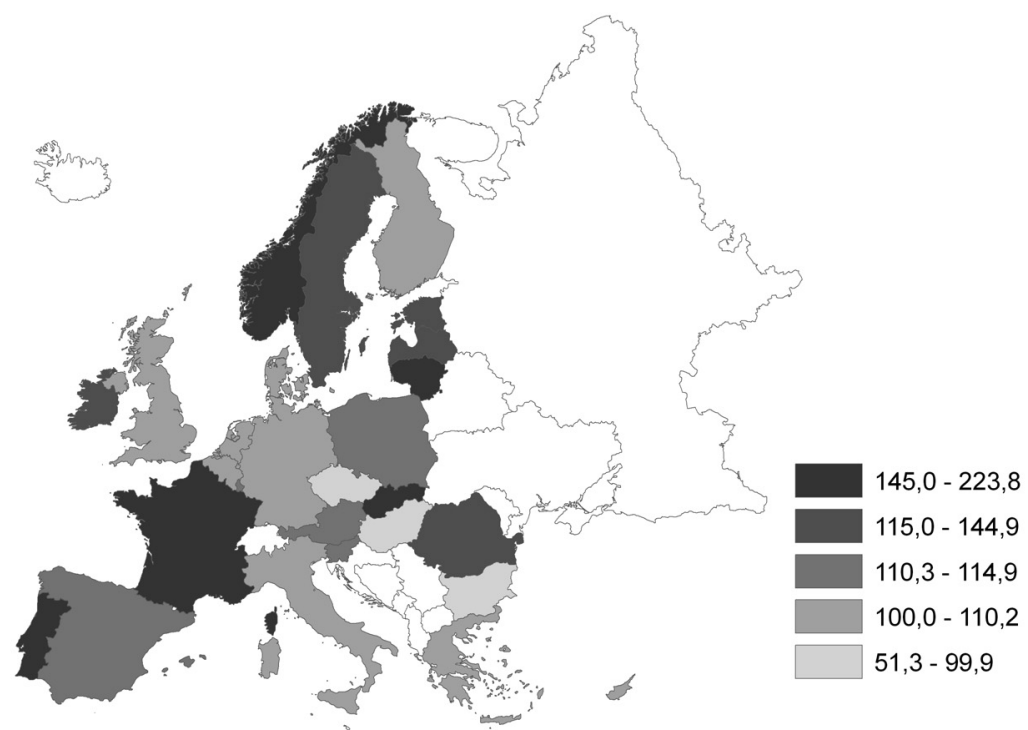

Figure 5. The changes in the number of SMEs in the years 2002-2006 $(2002=100)$

An analysis of employment changes in SMEs also shows a dynamic growth of this sector, albeit the indexes are slightly lower than in the case of changes in the number of enterprises (Figure 6). The highest increases in the years 2002-2006 were recorded in France, Poland, Latvia and Romania. A slight decline of employment in SMEs occurred in Czech Republic, Slovenia and Bulgaria.

Although the indexes of the development of SME sector and their share in economy seem to be very high, European Commission in its announcement (Communication 2005) pays attention to the fact that "the EU is not fully exploiting its entrepreneurial potential and is not producing enough start-ups. There are still too many factors, like the imbalance between risk and reward, weak social security coverage, and ignorance of what entrepreneurs really do, that tip the scales in favour of being employed rather than becoming self-employed. The Commission will step up its efforts to increase the appreciation of entrepreneurs in society, promote greater awareness of a career as an entrepreneur, foster entrepreneurial mindsets including the promotion of responsible entrepreneurship practices. The increasingly important role of entrepreneurship education will be underlined by a forthcoming Commission Communication on this key area". 


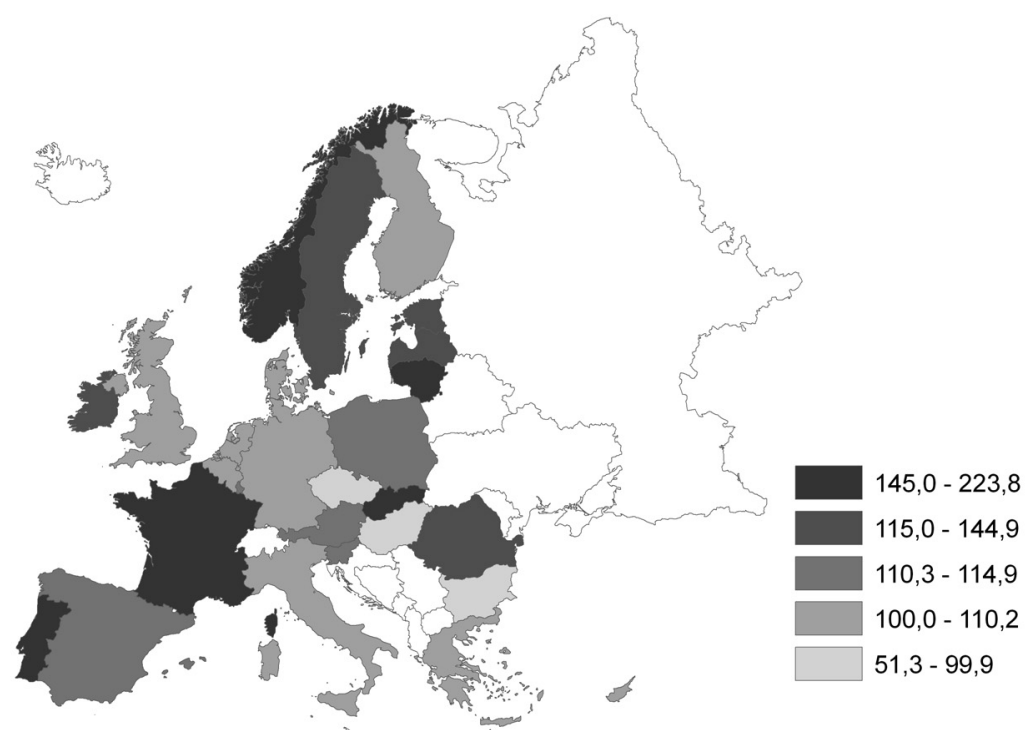

Figure 6. The changes in the number of employees in SMEs in the years 2002-2006 (2002=100)

It is a consecutive document, in which attention is drawn to an important role of entrepreneurship education in SMEs development. Undoubtedly, as recent studies on this research area show, there is also a positive link between entrepreneurship capital and the creation of new businesses as well as regional development (Audretsch and Keilbach 2004; Colombelli and Casia 2006; Zioło 2006; 2007). A question is raised then-is it possible to find a direct relation between the level of business education and the importance of SME sector in economy and the dynamics of its development?

\section{CONCLUDING REMARKS}

In light of above analysis it is difficult to answer this question explicitly. In countries which give much weight to business education (like Finland and Ireland) these indexes are not the highest as one can expect. As it seems the development of this sector and its role in economy is determined by several other factors (e.g. Najda and Wach 2007; Surdej 2003; Wach 2008; Zioło 2005) as economy police of a given state, legal-administrative determinants (including bureaucratic barriers) connected to starting up and running enterprises, impulses coming from international business environment, the shape of a market or even cultural determinants, associated with various traditions of people running their own businesses. In the short run an increase of enterprises from SME sector is influenced by economic situation which can be differentiated in particular EU countries. A general level of socio-economic development in a given country, including different types of social security is also of 
great significance. In countries, where workers are not afraid of dismissal and being out of work (for example because of limitations in employment reduction caused by restrictive regulations of labour law or high unemployment benefits), the willingness to start up own business can be lower. It can be one of the reasons of low indexes for such countries like France and Germany.

These issues requires then in-depth analysis in business education in individual countries and other factors shaping the development of entrepreneurship understood as running own enterprise. What is necessary in this scope are comparative studies in the European context aimed at promoting, so called, 'good practice' to prepare young people at school age to start their own firms. An international research project "Fifobi- fit for business: Developing business competencies in school", in which the authors are participating in, serves as an example of this kind of research. It is to be conducted during the years 2009-2011. The project investigates the current curricula within the final two years of compulsory education in the field of business education and pre-vocational education across the different European countries taking part in the study. This comparative analysis will identify the strengths and/or weaknesses within each of the national education systems with the aim of promoting best practice. Ultimately, the project will develop a model of innovation for other countries to follow and also help form the basis of a lifelong learning strategy for the education of students undertaking vocational studies. The project will allow for the collection of cross-country information and comparative assessment methodologies. This will help close an existing gap in research in the area of key competencies in business and pre-vocational education. Specifically, the analysis will concentrate on three areas. Firstly, the skills and knowledge held by learners of the general economic and business environment will be identified. Secondly, the extent to which personal responsibility and entrepreneurial thinking is encouraged in schools. Thirdly, it is to identify the core social competencies which are addressed in the teaching of young people in the context of occupational skills.

The project aims at accomplishing the following tasks:

- Development of criteria for exploring the situation of competence development in compulsory schools in the field of business and economy (including work experiences, project work, etc.) at national and international level.

- Analysis of the relevant curricula in the last two years of compulsory education.

- Undertaking interviews with teachers in the field of business and economy. Questioning schools about their range of provision, the strength and weaknesses of such a provision and the connections they have with the professional world (practical courses etc.)

- Establishing contact with employers, employment organisations and unions. Questioning employers, employers' organizations and representatives of unions about their involvement and experience in co-operating with schools.

- Evaluating the national approaches used within countries, offering both countryspecific and supranational comparisons. 
- Evaluating and comparing national findings at international level and selecting best practice approaches. Developing recommendations for the advancement of national solutions and EC-policies.

- Disseminating national and international outcomes by producing reports and publications in English and the national language. Informing key players in the field of education by disseminating information and organising workshops.

It is assumed that the implementation of the project will assist in better adaptation of teaching goals and contents within the scope of entrepreneurship education in the Member States of EU to challenges of forming business competencies among young people, which prospectively, should support a more dynamic growth of the sector of small and middle-size family firms.

\section{ACKNOWLEDGEMENTS}

This work was undertaken within the Fit For Business-Developing Business Competencies in School research project funded by European Union, European Commission: Education, Audiovisual and Culture Executive Agency; Grant programme: Lifelong Learning; Project Number 143356-LLP-1-2008-1-DE-KA1-KA1SCR.

\section{REFERENCES}

Audretsch, D. B. and Keilbach, M. (2004), Does entrepreneurship capital matter? Entrepreneurship Theory and Practice, 28, 419-430.

Baldaasarii, S. and Sivala, T. (2006) Towards more entrepreneurial generations, Enterprise Europe Online, <http://ec.europa.eu/enterprise/library/ee_online/art04_en.htm Business - Leaving Certificate Syllabus (1996), Government of Ireland, Dublin.

Citizenship. A scheme of work for key stage 4. Teacher's guide (2002), Qualifications and Curriculum Authority, London.

Colombelli, A. and Casia, L. (2006), Entrepreneurship as Regional Development Catalyst, ERSA conference papers, 46th Congress of the European Regional Science Association, ersa06p627, 1-21.

Communication from the Commission to the Council, the European Parliament, the European Economic and Social Committee and the Committee of the Regions: "Implementing the Community Lisbon Programme: Fostering entrepreneurial mindsets through education and learning", Brussels, 13.2.2006.

Communication from the Commission to the Council, the European Parliament, the European Economic and Social Committee and the Committee of the Regions: "Implementing the Community Lisbon Programme: Modern SME Policy for Growth and Employment", Brussels, 10.11.2005.

Council conclusions of 12 May 2009 on a strategic framework for European coop- 
eration in education and training 'ET 2020' (2009/C 119/02), Official Journal of the European Union, C 119/2, 28.5.2009.

Key Competencies. A developing concept in general compulsory education (2002), Eurydice, Brussels.

Najda, M. and Wach, K. (2007), Impact of integrated European business environment on SMEs cooperation strategies, Ekonomia journal, 17, 123-139.

National core curriculum for basic education (2004), Finnish National Board of Education, Vammalla.

Rachwał, T. (2009), Ocena projektu zmian podstawy programowej podstaw przedsiębiorczości (przedstawionej przez MEN w 2008 r. w ramach reformy systemu edukacji) in: Zioło, Z. and Rachwał, T. (eds.), Rola przedsiębiorczości w kształtowaniu społeczeństwa informacyjnego, Przedsiębiorczość-Edukacja, 5, Nowa Era, Warszawa-Kraków, 351-380.

Recommendation of the European Parliament and of the Council of 18 December 2006 on key competencies for lifelong learning (2006/962/EC), Official Journal of the European Union, L 394, 30.12.2006.

Surdej, A. (2003), SME Development in Poland: Policy and sustainability, in: McIntyre, R.J. and Dallago, B. (eds.), Small and Medium Enterprises in Transitional Economies, Palgrave Macmillan, London, 98-113.

Tracz, M. and Rachwał, T. (2007), Przedmiot podstawy przedsiębiorczości-założenia realizacji a przygotowanie nauczycieli, in: Zioło, Z. and Rachwał, T. (eds.), Rola przedsiębiorczoŚci w aktywizacji gospodarczej, Przedsiębiorczość-Edukacja, 3, Nowa Era, Warszawa-Kraków, 286-296.

Wach, K. (2008), Regionalne otoczenie matych $i$ średnich przedsiębiorstw, Wyd. Uniwersytetu Ekonomicznego, Kraków.

Zioło, Z. (2005), Światowe uwarunkowania rozwoju przedsiębiorczości, in: Zioło, Z. and Rachwał, T. (eds.), Przedsiębiorczość a współczesne wyzwania cywilizacyjne, Przedsiębiorczość-Edukacja, 1, Wydawnictwo „MiWa”, Kraków, 9-15.

Zioło, Z. (2006), Rola przedsiębiorczości w podnoszeniu konkurencyjności społeczeństwa i gospodarki, in: Zioło, Z. and Rachwał, T. (eds), Rola przedsiębiorczości w podnoszeniu konkurencyjności społeczeństwa i gospodarki, Przedsiębiorczość-Edukacja, 1, Wydawnictwo „MiWa”, Kraków, 10-17.

Zioło, Z. (2007), Rola przedsiębiorczości w aktywizacji gospodarczej-zarys modelu, in: Zioło, Z. and Rachwał, T. (eds.), Rola przedsiębiorczości w aktywizacji gospodarczej, Przedsiębiorczość-Edukacja, 3, Nowa Era, Warszawa-Kraków, 10-17. 


\section{8}

EUROPA XXI, 1-Sieć komunikacyjna Polski w europejskich procesach integracyjnych

EUROPA XXI, 2-Przestrzeń Europy Środkowej-przykłady transformacji

\section{9}

EUROPA XXI, 3 - Obszary szczególnej troski i nowych możliwości rozwoju na przykladzie Polski i Ukrainy

\section{0}

EUROPA XXI, 4-Powiązania handlowe Polski z Europą. Z debaty o przyszlym kształcie zjednoczonej Europy

EUROPA XXI, 5--Przestrzeń ekologiczna Polski. Dekolektywizacja rolnictwa i sytuacja zdrowotna w Europie Środkowej, Wschodniej i Poludniowo-Wschodniej

\section{1}

EUROPA XXI, 6-Integracja europejska-dylematy spójności i konwergencji regionalnej

\section{2}

EUROPA XXI, 7-Slovakia and Poland. Urban, social and demographic questions. Relation between neighbours

\section{3}

EUROPA XXI, 8-European space in the face of enlargement. The West to East European Trajectory Project

EUROPA XXI, 9-Polska i Europa. Kształtowanie przestrzeni wolności

EUROPA XXI, 10-Society and environment. Towns and settlement in Europe

\section{4}

EUROPA XXI, 11-Przestrzeń Europy. Przestrzeń Unii Europejskiej

\section{5}

EUROPA XXI, 12 - Central and Eastern Europe: changing spatial patterns of human activity

EUROPA XXI, 13-New spatial relations in new Europe

\section{6}

EUROPA XXI, 14 - Core and peripheral regions in Central and Eastern Europe

EUROPA XXI, 15-Regional periphery in Central and Eastern Europe

\section{7}

EUROPA XXI, 16-Regional development in Central Europe - cohesion or competitiveness

\section{8}

EUROPA XXI, 17-New functions of rural and industrial space in Central and Eastern Europe EUROPA XXI, 18-Territorial dilemmas of socio-economic development in Europe 


$$
\begin{aligned}
& \text { PL - ISSN 1429-7132 } \\
& \text { STANISEAW LESZCZYCKI }
\end{aligned}
$$

INSTITUTE OF GEOGRAPHY.AND SPATIAL ORGANIZATION, PAS WARSZAWA 